\title{
ONLINE-BASED MATHEMATICS LEARNING VIA DRAGONLEARN IN THE COVID-19 PANDEMIC ERA
}

\author{
Nita Ari Rochmahdani Safitri ${ }^{1}$, Muhammad Istiqlal ${ }^{2}$ \\ ${ }^{1} M I$ Ma'had Islam Kopeng \\ ${ }^{2}$ Program Studi Tadris Matematika LAIN Salatiga \\ E-mail:niethaari22.na@gmail.com ${ }^{1}$,m.istiqlal@iainsalatiga.ac.id
}

\begin{abstract}
The purpose of this study was to determine the process of implementing online learning via Dragonlearn Era Pandemic Covid-19. In addition to knowing the perceptions of students and teachers towards the application of online learning via Dragonlearn Era Pandemic Covid-19 and to find out the advantages and barriers to learning online via Dragonlearn Era Pandemic Covid-19. 19. This type of research uses a qualitative approach, data sources in this study include primary and secondary data sources. In the data collection technique, researchers used the method of observation, interviews, and documentation. In this study, respondents were 1 teacher and 3 students of MI Ma'had Islam Kopeng. The results of this study conclude that the process of implementing online learning via Dragonlearn Era Pandemic Covid-19 has been going well, with careful planning students can carry out learning smoothly so that teachers can evaluate through the available statistics page. Students are interested in learning like this because it produces a new learning atmosphere and many of their learning outcomes have been maximized. The teacher considers that the application of online learning via dragonlearn in the Covid-19 pandemic era has been effective because in addition to reducing the risk of the spread of Covid-19 they will also gain new experience and knowledge. The advantage is that they are more active and more confident in asking questions, they can access it anytime and anywhere. However, learning like this has obstacles that lie in the network. This learning also has disadvantages, namely that there are convoluted types of questions and the learning cannot be face-to-face so that the teacher cannot convey the material optimally.
\end{abstract}

Keywords: Online Learning, Dragonlearn, Pandemic Covid-19

\section{PEMBELAJARAN MATEMATIKA BERBASIS DARING VIA DRAGONLEARN DI ERA PANDEMIC COVID-19}

\begin{abstract}
Abtsrak
Tujuan penelitian ini adalah untuk mengetahui proses penerapan pembelajaran daring via Dragonlearn Era Pandemic Covid-19 selain itu untuk mengetahui persepsi siswa dan guru terhadap penerapan pembelajaran daring via Dragonlearn Era Pandemic Covid-19 serta untuk mengetahui keuntungan dan hambatan pembelajaran daring via Dragonlearn Era Pandemic Covid-19. Jenis penelitian ini menggunakan pendekatan kualitatif, sumber data dalam penelitian ini meliputi sumber data primer dan sekunder. Dalam teknik pengumpulan data peneliti menggunakan metode observasi, wawancara, dan dokumentasi. Dalam penelitian ini, responden sebanyak 1 orang guru dan 3 murid MI Ma'had Islam Kopeng. Hasil penelitian ini menyimpulkan bahwa proses penerapan pembelajaran daring via Dragonlearn Era Pandemic Covid-19 sudah berjalan dengan baik, dengan melakukan perencanaan yang matang siswa dapat melaksanakan pembelajaran dengan lancar sehingga guru dapat melakukan evaluasi melalui laman statistik yang tersedia. Siswa tertarik dengan pembelajaran
\end{abstract}


seperti ini karena menghasilkan suasana belajar yang baru dan hasil belajar merekapun banyak yang sudah maksimal. Guru menganggap bahwa penerapan pembelajaran daring via dragonlearn era pandemic Covid-19 sudah efektif karena selain mengurangi resiko terjadi penyebaran covid-19 mereka juga akan mendapat pengalaman dan pengetahuan yang baru. Keuntungannya adalah mereka jadi lebih aktif dan lebih percaya diri dalam bertanya, mereka dapat mengaksesnya kapan saja dan dimana saja. Namun pembelajaran seperti ini mempunyai hambatan yang terletak pada jaringan. Pembelajaran ini juga memiliki kekurangan yaitu terdapat pada jenis soal yang berbeli-belit dan pembelajarannya tidak bisa tatap muka sehingga guru tidak bisa menyampaikan materi dengan maksimal.

Kata Kunci: Pembelajaran daring, Dragonlearn, Pandemic covid-19.

\section{PENDAHULUAN}

Pendidikan jarak jauh merupakan pendidikan formal yang berbasis lembaga, dimana peserta didik, infrastrukturnya serta tenaga pengajarnya berada ditempat yang berbeda. Pendidikan jarak jauh ini memerlukan sistem telekomunikatif interaktif untuk menghubungkan keduanya dan berbagai sumber daya yang diperlukan didalamnya. Pembelajaran yang dilakukan dalam program pendidikan jarak jauh ini adalah melalui online yang secara khusus menggabungkan teknologi elektronika dan teknologi berbasis internet.

Proses pembelajaran memiliki peran penting sebagai proses untuk meningkatkan kualitas pendidikan. Pembelajaran jarak jauh adalah salah satu sistem pendidikan dengan kondisi pelajar dan pengajar berada di tempat yang berbeda. Hal itu tertuang dalam Undangundang Nomor 20 Tahun 2003 tentang Sistem Pendidikan Nasional pasal 31 yang menjelaskan Pendidikan jarak jauh berfungsi memberikan layanan pendidikan kepada kelompok masyarakat yang tidak dapat mengikuti pendidikan secara tatap muka atau regular. Dalam konteks yuridis formal, seperti yang termuat dalam PP No.17 Tahun 2010, bab IV tentang penyelenggaraan Pendidikan Jarak Jauh (PJJ), memiliki tujuan untuk perluasan dan pemerataan akses pendidikan, serta meningkatkan mutu dan relevansi pendidikan.

Virus Corona atau severe acute respiratory syndrome coronavirus 2 (SARS-CoV2) adalah virus yang menyerang sistem pernapasan. Penyakit karena infeksi virus ini disebut COVID-19. Virus Corona bisa menyebabkan gangguan ringan pada sistem pernapasan, infeksi paru-paru yang berat, hingga kematian. Severe acute respiratory syndrome coronavirus 2 (SARS-CoV-2) yang lebih dikenal dengan nama virus Corona adalah jenis baru dari coronavirus yang menular ke manusia. Hampir dari sebagian negara di dunia terjangkit wabah tersebut. Salah satu negara yang terjangkit virus tersebut ialah Indonesia. Yang kemudian, memaksa setiap dari kegiatan kita terhenti, baik kegiatan yang berhubungan dengan ekonomi, sosial, pendidikan dan lainnya.

Covid-19 membuat setiap kegiatan menjadi terhambat, salah satunya kegiatan belajar mengajar disekolah-sekolah. Faktanya siswa dituntut untuk belajar di rumah karena peraturan pemerintah yang mengahruskan kita untuk belajar, bekerja dan beribadah di rumah. Begitupun para guru yang dijadwalkan untuk tetap berangkat/piket ke sekolah walaupun para siswa belajar di rumah, namun tetap dalam protokol kesehatan yang dianjurkan oleh pemerintah yang hanya beberapa guru yang berangkat dalam sehari karena harus menerapkan social distancing.

E-learning merupakan singkatan dari Elektronic Learning, merupakan cara baru dalam proses belajar mengajar yang menggunakan media elektronik khususnya internet sebagai sistem pembelajarannya. E-learning merupakan dasar dan konsekuensi logis dari perkembangan teknologi informasi dan komunikasi. E-learning dalam arti luas bisa 
mencakup pembelajaran yang dilakukan di media elektronik (internet) baik secara formal maupun informal.

Pembelajaran Daring (dalam jaringan) merupakan belajar secara online melalui media-media yang ditentukan. Siswa dan guru tetap bisa berdiskusi, begitupun dengan temanteman kelompoknya. Media yang digunakan dapat bermacam-macam, yang biasa digunakan biasanya zoom, google class, google meet, teams, dragonlearn, dsb. Pembelajaran daring memang membutuhkan tanggung jawab, kemandirian dan ketekunan pribadi, karena tidak ada yang mengontrol selain dirinya sendiri. Mereka harus mendownload dan membaca materi, menjawab quiz/soal serta mensubmit tugas secara mandiri. Kapabilitas pembelajaran online akan memberikan kinerja mahasiswa yang lebih bagus dibanding dengan pembelajaran konvensional, karena selain berpengetahuan mereka juga melek teknologi.

Dragonlearn merupakan salah satu media yang dapat digunakan untuk membantu pembelajaran daring terutama pada mata pelajaran matematika tingkat sekolah dasar. Dragonlearn adalah platform pembelajaran Matematika online dengan kurikulum yang interaktif untuk kelas 1-6. Dragonlearn merupakan sebuah pendekatan individual ke setiap siswa. Dragonlearn diciptakan sedemikian rupa, agar anak-anak didik mampu mempelajari materi pelajaran yang akan bergerak dari tema ke tema hingga mereka benar-benar menguasai tema tersebut. Setelah pelajaran ini, siswa akan mampu mengatasi tugas-tugas apapun yang ada di buku pelajaran sekolah dengan mudah.

Tujuan penelitian ini adalah untuk mengetahui proses penerapan pembelajaran daring via Dragonlearn Era Pandemic Covid-19 selain itu untuk mengetahui persepsi siswa dan guru terhadap penerapan pembelajaran daring via Dragonlearn Era Pandemic Covid-19 serta untuk mengetahui keuntungan dan hambatan pembelajaran daring via Dragonlearn Era Pandemic Covid-19.

\section{METODE PENELITIAN}

Pendekatan penelitian ini menggunakan metode studi kasus kualitatif yang digunakan untuk mendapatkan informasi proses penerapan pembelajaran daring via Dragonlearn Era Pandemic Covid-19 selain itu untuk mengetahui persepsi siswa dan guru terhadap penerapan pembelajaran daring via Dragonlearn Era Pandemic Covid-19 serta untuk mengetahui keuntungan dan hambatan pembelajaran daring via Dragonlearn Era Pandemic Covid-19.

Dalam penelitian ini, responden sebanyak 1 orang guru dan 3 murid. Untuk tujuan kerahasiaan, responden diberi inisial R1, R2, R3 dan R4. Wawancara semi-terstruktur dilakukan dan daftar pertanyaan disusun untuk wawancara dikembangkan berdasarkan literatur terkait. Responden untuk penelitian ini adalah guru dan murid di MI Ma'had Islam Kopeng.

Tabel 1. Profil Responden

\begin{tabular}{|c|l|r|l|}
\hline Initial & $\begin{array}{c}\text { Jenis } \\
\text { Kelamin }\end{array}$ & Usia & Pendidikan \\
\hline R1 & Perempuan & 25 & S1 \\
\hline R2 & Perempuan & 10 & SD/MI \\
\hline R3 & Perempuan & 11 & SD/MI \\
\hline R4 & Laki-Laki & 12 & SD/MI \\
\hline
\end{tabular}

Metode pengumpulan dengan primer dengan wawancara semi-terstruktur sedangkan data sekunder dikumpulkan dari data yang dipublikasikan seperti artikel jurnal-jurnal dan buku. Semua responden menyediakan informasi sebelum wawancara. Untuk tempat wawancara dilakukan di kediaman R1 dan yang lain menggunakan via video call karena sedang pandemic. Semua wawancara, dengan izin dan persetujuan yang ditandatangani, 
direkam secara audio dan kemudian ditranskrip secara verbal.

Untuk menggali dan mendapatkan informasi proses penerapan pembelajaran daring via Dragonlearn Era Pandemic Covid-19 selain itu untuk mengetahui persepsi siswa dan guru terhadap penerapan pembelajaran daring via Dragonlearn Era Pandemic Covid-19 serta untuk mengetahui keuntungan dan hambatan pembelajaran daring via Dragonlearn Era Pandemic Covid-19, diajukan pertanyaan-pertanyaan berikut:

1. Apakah selama pandemic ini pembelajaran dilaksanakan dengan menggunakan dragonlearn semua bu?

2. Apakah selama ini proses pembelajaran daring via dragonlearn era pandemic covid-19 sudah terlaksana dengan baik bu?

3. Sebelum melakukan pembelajaran daring menggunakan dragonlearn, apa saja yang sekolah dan ibu persiapkan agar pembelajaran tersebut dapat berjalan dengan lancar?

4. Setelah melakukan persiapan, bagaimana cara memulai pembelajaran tersebut?

5. Berapa lama waktu yang dibutuhkan untuk menyelesaikan satu pembelajaran menggunakan dragonlearn?

6. Setelah semua siswa mengikuti pembelajaran, bagaimana cara anda melakukan penilaian?

7. Apabila terdapat siswa yang mendapat nilai kurang, apa yang anda lakukan agar siswa tersebut dapat memperbaiki nilainya?

8. Apakah selama ini proses pembelajaran daring via dragonlearn era pandemic covid-19 sudah terlaksana dengan baik dek?

9. Dalam pembelajaran seperti ini, apa pengaruh yang anda rasakan setelah melakukan pembelajaran daring via dragonlearn era pandemic covid-19?

10. Sejauh ini apakah hasil belajarnya memuaskan atau justru sebaliknya?

11. Apakah menurut kalian pembelajarannya menarik?

12. Apakah selama ini proses pembelajaran daring via dragonlearn era pandemic covid-19 sudah terlaksana dengan baik bu?

13. Dalam pembelajaran seperti ini, apa pengaruh yang ibu rasakan setelah melakukan pembelajaran daring via dragonlearn era pandemic covid-19?

14. Sejauh mana hasil belajar siswa dengan daring via dragonlearn era pandemic covid-19 ini bu?

15. Menurut anda, bagaimana cara untuk memaksimalkan pembelajaran daring via dragonlearn era pandemic covid-19?

16. Apakah dengan pembelajaran daring via dragonlearn ini siswa lebih aktif dalam proses pembelajaran?

17. Bagaimana tanggung jawab siswa dalam mengikuti pembelajaran daring via dragonlearn era pandemic covid-19?

18. Selama pembelajaran, apakah terdapat siswa yang tidak pernah mengikuti pembelajaran? Jika ada, bagaimana cara ibu agar siswa tersebut mau mengikuti pembelajaran?

19. Menurut ibu, Apakah dragonlearn ini sudah efektif digunakan dalam pembelajaran era pandemic Covid-19?

20. Adakah faktor-faktor penghambat dalam melakukan pembelajaran ini?

21. Apa saja faktor-faktor penghambat dalam memaksimalkan pembelajaran daring via dragonlearn era pandemic covid-19?

22. Adakah keuntungan setelah menggunakan pembelajaran daring via dragonlearn era pandemic covid-19 ini bu?

23. Setelah melakukan pembelajaran seperti ini, apa saja kelebihan dan kekurangan dari pembelajaran daring via dragonlearn era pandemic covid-19 ini bu? 


\section{PEMBAHASAN}

\section{Hasil Wawancara}

Tujuan penelitian ini adalah untuk mengetahui proses penerapan pembelajaran daring via Dragonlearn Era Pandemic Covid-19 selain itu untuk mengetahui persepsi siswa dan guru terhadap penerapan pembelajaran daring via Dragonlearn Era Pandemic Covid-19 serta untuk mengetahui keuntungan dan hambatan pembelajaran daring via Dragonlearn Era Pandemic Covid-19.

Seorang responden $\mathrm{R} 1$ memberikan pernyataan :

"Kalau mapel matematika sudab menggunakan dragonlearn semua mbak, tapi kalau mapel lainnya tidak" (R1).

"Alhamdulillah mbak sudah berjalan dengan baik" (R1).

"Tadi dalam perencanaan pembelajaran ini guru dan sekolah sama-sama terlibat. Pihak sekolah atau lebih tepatnya kepala sekolah menyiapkan hal tersebut dengan mengecek gawai yang digunakan setiap guru sudah memadai atau belum. Kemudian kepala sekolah mengecek. kesiapan setiap guru, apakah guru tersebut sudah mengerti cara penggunaan platform tersebut atau belum, karena belum semua guru menguasai penggunaan dragonlearn maka kepala sekolah mensosialisasikan penggunaan dragonlearn agar semua guru menguasai dragonlearn tersebut.

Selain kepala sekolah, guru juga ikut berperan dalam melakukan perencanaan. Setiap guru memastikan semua siswa/ wali murid dapat mengoperasikan dragonlearn. Jika semua wali murid sudah menyetujui dan sudah dipastikan dapat menggunakan dragonlearn tersebut, maka pembelajaran daring siap untuk dimulai. Tapi sebelum kita memulai pembelajaran, kita harus memastikan semua wali murid dapat mendaftar dalam dragonlearn ini mbak. Kalau sudah terdaftar semua satu kelas, barulah kita dapat memulai pembelajaran menggunakan dragonlean ini" (R1).

"Untuk memulai pembelajaran ini saya sebagai guru harus memastikan dulu kalau semua siswa sudah bisa masuk dalam dragonlearn ini. Nah kalau semua sudab bisa masuk, saya akan mulai memberikan panduan melalui whatsapp grup bagaimana cara mengerjakan soal, berapa lama waktunya dan lain sebagainya mbak.

Dalam dragonlearn ini sudah banyak bank soal yang sesuai dengan materi untuk masing-masing kelas. Ini mbak saya kasih lihat contoh beberapa bab yang ada dikelas IV. Kalau kelas saya kan kelas IV mbak jadinya saya menggunakan dragonlearn untuk kelas IV. Sebelum memulai mengerjakan soal di dragonlearn ini, anak-anak saya ajak untuk mempelajari materi yang ada di buku. Setelah selesai mempelajari materi yang ada dibuku langsung bisa lanjut mengerjakan soal-soal yang ada di dragonlearn ini." (R1).

"setiap materi kan ada sub materinya mbak, nah setiap sub materi tersebut mempunyai beberapa soal yang harus dikerjakan. Jika jawabannya benar maka bisa melanjutkan ke soal selanjutnya, begitu seterusnya. Tapi kalau dalam mengerjakan soal ada yang salah maka dari aplikasi tersebut otomatis akan memberikan tambahan soal biasanya satu soal salah maka akan ditambah 3 soal. Jadinya kalau salah terus ya nambah terus mbak soalnya, malah tambah puyeng kan, hehe (R1).

"Setiap materi saya kasih waktu 2 minggu untuk pengerjaannya mbak, jadi kalau misal anak yang rajin tidak sampai 2 minggu sudah selesai tapi kalau anak yang malas 2 minggu itu belum tentu bisa selesai" (R1).

"Penilaiannya sudah otomatis dari aplikasinya mbak, di situ sudah tertera statistik untuk hasil dari masing-masing anak bisa dilihat dilaman tersebut. Kalau misal ada yang sudah mengerjakan semuanya dengan benar maka prosentasenya sudah 100\%, jika ada yang belum selesai mengerjakan soal nanti prosentasenya kelihatan mbak. Jadi untuk penilaiannya ya kita libat pada prosentase akbir dari pembelajaran tersebut mbak." (R1).

"Saya itu guru yang riwil mbak, setiap hari saya pantau dari statistik. kemajuan setiap siswa. Jadi misal dihari pertama ada anak yang belum mengerjakan sama sekali, kan keliatan dari statistiknya mbak kalau masib $0 \%$ saya langsung chat di whatsapp grup mbak, say a langsung chat di whatsapp grup biar mereka 
punya rasa malu dan dapat motivasi untuk. cepat menyeselesaikan soal-soal seperti teman-temannya mbak. Setiap hari saya selalu chat di whatsapp grup untuk. mengingatkan siswa-siswa agar dapat menyelesaikan soal-soalnya tepat waktu dan agar mendapat nilai yang maksimal" (R1).

Beberapa responden memberikan pernyataan :

"baik bu, karena saya sudah menyelesaikan semua soal dengan tepat waktu"(R2).

"iya bu sudab berjalan dengan baik."(R3).

"iya bu sudab"(R4).

"saya jadi tambah rajin bu soalnya kalau tidak. belajar nanti nilainya jadi jelek. bu kan malu nanti sama teman-teman" (R2).

"jadi rajin bu, soalnya mengerjakannya di batasi waktu kalau tidak cepat mengerjakan nanti gak selesai bu” (R3)

"Jadi sering mengerjakan soal bu karena soalnya itu banyak. banget bu jadi berkurang waktu bermain saya” (R4).

"punyaku sudah 100\% bu soalnya sudah saya kerjakan semua" (R2).

"hasil belajarnya bagus bu, saya bisa mengerjakan semua soal tapi ya ada yang tanya caranya sama bu Aniq kalau tidak tahu cara mengerjakannya" (R3).

"basilnya 100\% sib bu tapi soalnya itu lho sulit-sulit jadi harus Tanya dulu sama teman-teman sama bu Aniq juga” (R4).

"pembelajarannya menarik bu banyak games dan gambar-gambarmya saja jadi senang" (R2).

"Menarik bu bagus pembelajarannya, dari pada pakai buku saya lebih suka pembelajaran seperti ini" (R3).

"Bagus bu saya lebih suka pembelajaran seperti ini bu soalnya bisa lama pegang hp, behe" (R4).

Seorang responden R1 memberikan pernyataan :

"Alhamdulillah sudah berjalan dengan baik mbak" (R1).

"kalau pengarubnya buat saya ya saya jadi sering pegang gawai mbak, buat memantau statistik kemajuan dari setiap siswa” (R1).

"Hasil belajarnya sebagian besar siswa mendapatkan nilai yang bagus, walaupun ada 2 siswa yang benarbenar tidak mengerjakan sama sekali soal yang ada. Namun yang lain mereka sudah berusaha agar mendapatkan basil yang maksimal" (R1)

"saya sering memberikan motivasi kepada anak-anak melalui chat di whatsapp grup mengajak mereka serius dalam belajar agar dapat mengerjakan soal dengan mudah. Saya pikir dengan seperti itu wali murid akan tergerak hatinya dan selalu memantau kemajuan anaknya" (R1)

"lebih aktif mbak, terbukti ketika mereka mengerjakan soal dan mendapatkan yang agak sulit, mereka langsung chat saya mbak. Lewat chat mereka lebih berani bertanya ketimbang saat pembelajaran di dalam kelas. Mungkin karena tidak langsung bertatap muka mereka menjadi lebih berani” (R1)

"rasa tanggung jawab mereka besar mbak, terbukti mereka jadi lebih sering belajar agar dapat menyelesaikan soal-soal yang ada" (R1).

"ada mbak, 2 anak. Alasannya yang satu HPnya memang dibawa orang tuanya bekerja dan pulangnya malam, jadi anak tersebut tidak ada waktu untuk mengerjakan soal-soalnya. Yang satunya lagi punya HP sendiri mbak tapi ya memang anaknya itu super ndablek tidak pernab mau belajar di rumah, kerjaannya cuma main trus. Berkali-kali sudah saya tegur tetapi ya mau gimana lagi mbak, memang anaknya susah. Jadi ya saya memilih untuk fokus sama anak-anak yang mau berusaha mbak daripada mengurusi satu anak tapi yang lainnya tidak kesentub" (R1).

"menurut saya sudah efektif mbak, karena memang ini solusi agar siswa tetap belajar dari rumah selain itu mereka juga nambah pengetahuan dan pengalaman mbak. Dengan pembelajaran daring via dragonlearn ini tentu lebih mengenalkan mereka terbadap teknologi di era millennial ini” (R1). 
"kelebihannya ya mereka jadi mendapat pengalaman baru mbak, mereka juga nambah pengetahuan karena soal yang ada sudah termasuk soal HOTS jadi tidak monoton seperti itu-itu aja. Selain itu mereka juga bisa mengerjakan sesuka mereka tanpa harus duduk di kels maupun pada jam tertentu" (R1).

"kalau kekurangannya itu terdapat pada jenis soal-soal yang menurut saya berbelit-belit sehingga anak. jadi bingung karena anak. kurang pengetahuan dan pengalaman jadi soal beda sedikit dari materi mereka langsung bingung. Selain itu pembelajaran seperti ini menurut saya membuang-buang waktu karena siswa jadi fokus pada satu pelajaran saja sehingga yang lain jadi terabaikan. Selain itu pembelajaran seperti ini kan tidak bisa tatap muka mbak, jadi ya saya tidak bisa menyampaikan materi dengan maksimal kalau siswa ada yang belum paham ya jadi susah" (R1).

"keuntungannya itu mengerjakannya tidak, harus hari itu juga mbak, karena saya kasih waktu 2 minggu untuk menyelesaikan satu materi. Jadi siswa diberi waktu untuk bertanya bisa sama temannya bisa sama saya yang penting mereka punya greget untuk menyelesaikan soalnya. Selain itu mereka jadi lebih PD untuk. bertanya lebih berani karena kalau di dalam kelas hanya anak tertentu yang mau bertanya yang lain hanya diam walaupun belum paham karena mereka malu untuk bertanya" (R1)

Beberapa responden memberikan pernyataan :

"ada bu, hpnya kan barengan sama orang tua padahal orang tua saya kerja. tambah lagi sinyalnya bilangbilang jadi lama mengerjakannya" (R2).

"ada bu, punya saya tu sering eror bolak-balik sendiri gitu jadi harus ngulangin lagi kan jadi lama" (R3). "ada bu, kuota bu penghambatnya, hehe soalnya saya kalau beli yang murah jadi cepet habis" (R4).

"faktor penghambatnya itu ada di kuota mbak, soalnya pibak sekolab kan tidak menyediakan kuota untuk pembelajaran jadinya kita sebagai guru harus modal sendiri. Padahal anak-anak tu masih awam sama aplikasi ini jadi dikit-dikit di screenshot dikirim trus tanya, itupun tidak. cuma satu anak aja tapi hampir semua mbak, kebayang kan saya harus menjawab pertanyaan satu-satu dan pertanyaannya itu hampir sama semua. Selain itu jaringan diponsel yang mereka bawa itu tidak stabil ya maklumlah ya mbak karena mereka bidup dlereng gunung dan pedesaan jadi jaringan itu gak selancar di kota, nah itu berdampak pada aplikasi yang sering eror dan bolak-balik. ke awal lagi” (R1).

\section{Proses penerapan pembelajaran daring via Dragonlearn Era Pandemic Covid-19 mata pelajaran matematika pada siswa kelas IV MI Ma'had Islam Kopeng}

Penerapan pembelajaran daring via Dragonlearn Era Pandemic Covid-19 mata pelajaran matematika pada siswa kelas IV MI Ma'had Islam Kopeng sudah berjalan dengan baik. Ditunjukkan dari data yang dikemukakan oleh AA bahwa proses tersebut dilakukan melalui 3 tahap yaitu perencanaan, pelaksanaan dan evaluasi.

Perencanaan pembelajaran melibatkan semua pihak antara lain guru, kepala sekolah wali murid dan siswa. Semua pihak mempunyai peran masing-masing dan harus dipastikan sudah mempunyai kesiapan semua. Dilanjutkan dengan pelaksanaan pembelajaran dimana sebelum siswa mengerjakan soal, guru terlebih dahulu mengajak siswa untuk mempelajari materi yang ada di buku paket maupun LKS. Setelah selesai mempelajari barulah siswa diajak untuk mengerjakan soal sesuai dengan materi yang ditentukan.

Setelah pelaksanaan selesai barulah guru melakukan evaluasi. Guru melakukan penilaian melalui laman statistik yang tersedia. Dalam laman statistik dapat dilihat perkembangan kemajuan setiap siswa.

Dengan demikian, dapat disimpulkan bahwa proses penerapan pembelajaran daring via Dragonlearn Era Pandemic Covid-19 sudah berjalan dengan baik, dengan melakukan perencanaan yang matang siswa dapat melakukan pembelajaran dengan lancar sehingga guru dapat melakukan evaluasi melalui laman statistik yang tersedia.

\section{Persepsi siswa terhadap penerapan pembelajaran Daring via Dragonlearn Era}




\section{Pandemic Covid-19 mata pelajaran matematika}

Pembelajaran daring via dragonlearn era pandemic covid-19 sangat menarik bagi siswa karena menghasilkan suasana belajar yang baru bagi siswa dan siswa lebih nyaman dalam belajar pada era pandemic Covid-19. Selain menghasilkan suasana baru, penerapan pembelajaran daring via dragonlearn era pandemic Covid-19 memberikan pengaruh positif untuk para siswa yaitu siswa jadi lebih giat belajar agar mendapat nilai yang maksimal. Hal tersebut dibuktikan dengan hasil belajar siswa yang hampir semua dapat mengikuti pembelajaran daring via dragonlearn era pandemic covid-19. Media yang digunakan juga lebih bervariatif sehingga mereka lebih tertarik dalam melaksanakan pembelajaran daring via dragonlearn era pandemic covid-19.

Dengan demikian dapat disimpulkan bahwa persepsi siswa terhadap pembelajaran daring via dragonlearn era pandemic covid-19 sangat menarik bagi siswa karena menghasilkan suasana belajar yang baru sehingga siswa lebih tertarik dan semangat untuk mencobanya dan hasil belajar merekapun banyak yang sudah maksimal.

\section{Persepsi guru terhadap penerapan pembelajaran Daring via Dragonlearn Era Pandemic Covid-19 mata pelajaran matematika}

Penerapan pembelajaran daring via dragonlearn era pandemic Covid-19 sudah berjalan dengan baik akan tetapi mempunyai pengaruh yaitu guru jadi sering memegang gawai untuk memantau statistik kemajuan siswa dalam mengerjakan soal-soal yang ada di dragonlearn. Pembelajaran sudah berjalan dengan baik hal ini dapat dibuktikan bahwa hanya ada 2 siswa yang tidak mengikuti pembelajaran ini dengan alasan masing-masing yang berbeda. Guru menganggap pembelajaran daring via dragonlearn era pandemic Covid-19 sudah efektif terapkan karena dapat mengurangi resiko menyebarnya Covid-19 dan siswa juga akan mendapatkan pengalaman dan pengetahuan yang baru.

Dengan demikian dapat disimpulkan bahwa persepsi guru terhadap penerapan pembelajaran daring via dragonlearn era pandemic Covid-19 sudah baik. Akan tetapi tetap ada siswa yang tidak mengerjakan soal sama sekali dan guru memutuskan untuk lebih fokus dengan anak-anak yang mau berusaha. Guru menganggap bahwa penerapan pembelajaran daring via dragonlearn era pandemic Covid-19 sudah efektif karena selain mengurangi resiko terjadi penyebaran covid-19 mereka juga akan mendapat pengalaman dan pengetahuan yang baru.

Kelebihan dari penerapan pembelajaran daring via dragonlearn era pandemic Covid-19 adalah mereka mendapat pengalaman baru dan nambah pengetahuan karena soal yang ada sudah termasuk soal HOTS jadi tidak monoton. Selain itu mereka juga dapat mengerjakannya dimana saja dan kapan saja.

Selain kelebihan pembelajaran seperti ini juga memiliki kekurangan yaitu pembelajaran seperti ini terdapat pada jenis soal yang berbeli-belit sehingga mengakibatkan siswa menjadi bingung dan pembelajaran seperti ini mengakibatkan terabaikannya pelajaran lain karena mereka hanya fokus pada pelajaran ini saja dan tidak bisa tatap muka sehingga guru tidak bisa menyampaikan materi dengan maksimal.

\section{Keuntungan dan hambatan pembelajaran Daring via Dragonlearn Era Pandemic Covid-19 mata pelajaran matematika}

Keuntungan dari pembelajaran seperti ini adalah mereka jadi lebih aktif dan lebih percaya diri dalam bertanya. Hambatan dari penerapan pembelajaran daring via dragonlearn era pandemic Covid-19 terletak pada jaringan, karena jaringan sangat berpengaruh terhadap kelancaran penggunaan aplikasi, mereka hidup di lereng gunung dan pedesaan jadi jaringan internetnya masih lambat dan sering hilang selain itu setiap siswa tidak mempunyai HP sendiri sehingga mereka harus menunggu orang tua pulang dari bekerja serta pihak sekolah tidak 
menyediakan solusi untuk memperlancar pelaksanaan pembelajaran daring.

Dengan demikian dapat disimpulkan bahwa keuntungan dari pembelajaran seperti ini adalah mereka jadi lebih aktif dan lebih percaya diri dalam bertanya karena kelebihan dari penerapan pembelajaran daring via dragonlearn era pandemic Covid-19 adalah mereka mendapat pengalaman baru dan menambah pengetahuan serta dapat mengaksesnya kapan saja dan dimana saja. Namun juga mempunyai hambatan yang terletak pada jaringan, karena jaringan sangat berpengaruh terhadap kelancaran penggunaan aplikasi mereka hidup di lereng gunung dan pedesaan jadi jaringan internetnya masih lambat dan sering hilang selain itu setiap siswa tidak mempunyai HP sendiri sehingga mereka harus menunggu orang tua pulang dari bekerja serta pihak sekolah tidak menyediakan solusi untuk memperlancar pelaksanaan pembelajaran daring. Selain itu pembelajaran ini memiliki kekurangan yaitu terdapat pada jenis soal yang berbeli-belit dan pembelajarannya tidak bisa tatap muka sehingga guru tidak bisa menyampaikan materi dengan maksimal.

\section{SIMPULAN}

Proses penerapan pembelajaran daring via Dragonlearn Era Pandemic Covid-19 sudah berjalan dengan baik, dengan melakukan perencanaan yang matang siswa dapat melakukan pembelajaran dengan lancar sehingga guru dapat melakukan evaluasi melalui laman statistik yang tersedia.

Persepsi siswa terhadap pembelajaran daring via dragonlearn era pandemic covid-19 sangat menarik bagi siswa karena menghasilkan suasana belajar yang baru sehingga siswa lebih tertarik dan semangat untuk mencobanya dan hasil belajar merekapun banyak yang sudah maksimal. Persepsi guru terhadap penerapan pembelajaran daring via dragonlearn era pandemic Covid-19 sudah baik. Akan tetapi tetap ada siswa yang tidak mengerjakan soal sama sekali dan guru memutuskan untuk lebih fokus dengan anak-anak yang mau berusaha. Guru menganggap bahwa penerapan pembelajaran daring via dragonlearn era pandemic Covid-19 sudah efektif karena selain mengurangi resiko terjadi penyebaran covid-19 mereka juga akan mendapat pengalaman dan pengetahuan yang baru.

Keuntungan dari pembelajaran seperti ini adalah mereka jadi lebih aktif dan lebih percaya diri dalam bertanya karena kelebihan dari penerapan pembelajaran daring via dragonlearn era pandemic Covid-19 adalah mereka mendapat pengalaman baru dan menambah pengetahuan serta dapat mengaksesnya kapan saja dan dimana saja. Namun juga mempunyai hambatan yang terletak pada jaringan, karena jaringan sangat berpengaruh terhadap kelancaran penggunaan aplikasi mereka hidup di lereng gunung dan pedesaan jadi jaringan internetnya masih lambat dan sering hilang selain itu setiap siswa tidak mempunyai HP sendiri sehingga mereka harus menunggu orang tua pulang dari bekerja serta pihak sekolah tidak menyediakan solusi untuk memperlancar pelaksanaan pembelajaran daring. Selain itu pembelajaran ini memiliki kekurangan yaitu terdapat pada jenis soal yang berbelibelit dan pembelajarannya tidak bisa tatap muka sehingga guru tidak bisa menyampaikan materi dengan maksimal.

\section{DAFTAR PUSTAKA}

Antapedia. 2020. Apakah Platform www.dragonlearn.org itu? http://www.antapedia.com (diakses pada 30 Juni 2020, pukul 22.06 WIB)

Bungin, Burhan. 2013. Penelitian Kualitatif. Jakarta: Prenada Media Group.

Dewi, Wahyu Aji Fatma. 2020. Dampak Covid-19 Terhadap Implementasi Pembelajaran

Daring di Sekolah Dasar. Jurnal Ilmu Pendidikan. 2 (1): 55-61.

Erikanto, Chandra. 2016. Teori Belajar dan Pembelajaran. Yogyakarta: Media Akademi. 
Hafidz, M. N. 2020. Update Corona Indonesia dan Dunia Senin 15 Juni 2020. https://ayobandung.com/read/2020/06/15/95201/update-corona-indonesia-dandunia-senin-15-juni-2020 (diakses pada tanggal 15 Juni 2020, pukul 22.33 WIB)

Hakiman. 2020. Pembelajaran Daring. https://iain-

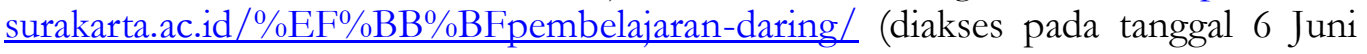
2020, pukul 15.06 WIB)

Helaluddin \& Hengki Wijaya. 2019. Analisis Data Kualitatif Sebuah Tinajuan Teori dan Praktik.: Sekolah Tinggi Theologi Jaffray. https://books.google.co.id/books?idlf7ADwAAQBAJ\&printsec=frontcove

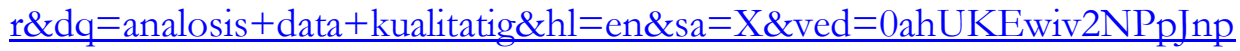
AhWLdn0KHZFcAfMQ6AEIKTAA\#v= onepage\&q $=$ analosis $\% 20$ data $\% \mathrm{k}$ ualitatig\&f=false (diakses pada tanggal 1 Juli 2020, pukul 13.25 WIB).

Heruman. 2010. Model Pembelajaran Matematika SD. Bandung: Remaja Rosda Karya.

Ibadurrahman, Muhammad Alief. 2020. Coronavirus Asal Usul, Penyebaran, Dampak, dan Metode Pencegahan Efektif Pandemi Covid-19. https://books.google.co.id/books?id=dRXbDwAAQBAJ\&hl=id. (diakses pada tanggal 21 Mei 2020, pukul 22.12 WIB).

Imania, K. A dkk. 2019. Rancangan Pengembangan Instrumen Penilaian Pembelajaran Berbasis Daring. Jurnal PETIK. 5 (1): 31-47.

Kompri. (2017). Belajar; Faktor-faktor yang Mempengaruhinya. Yogyakarta: Media Akademi. Maskun, \& Rachmedita, V. (2018). Teori Belajar dan Pembelajaran. Yogyakarta: GRAHA ILMU.

Miswar, Dedy dkk. 2016. Perbedaan Penerapan Model Problem Based Learning Pada Hasil Belajar geografi. Yogyakarta: Media Akademi.

Moleong, Lexy J. 2008. Metodologi Penelitian Kualitatif (Edisi Revisi). Bandung: PT Remaja Rosdakarya.

2011 . Metodologi Penelitian Kualitatif Edisi Revisi. Bandung: PT Remaja Rosdakarya.

Muliawan, Jasa Ungguh. 2014. Metodologi Penelitian Pendidikan dengan Studi Kasus. Yogyakarta: Gava Media.

Multyaningsih, Endang. 2014 . Metode Penelitian Terapan Bidang Pendidikan. Bandung: Alfabeta.

Nai, Firmina Angela. 2017. Teori Belajar dan Pembelajaran Implementasi dalam Pembelajaran Bahasa Indonesia. Yogyakarta: Deepublish.

Oka, G. P., \& Tastra, I. D. (2015). Massive Open Online Course: Web Pembelajaran Masa Depan. Yogyakarta: Teknosain.

Pane, M. D. 2020. Virus Corona. https://www.alodokter.com/virus-corona (diakses pada tanggal 13 Juni 2020, pukul 22.42 WIB)

Parinduri, Rifdah Hasan. 2019. Peranan LAPER BE-ON (Layanan Perpustakaan On line) untuk pendidikan jarak jauh dalam era globalisasi. Jurnal Iqra'. 13(1).

Peraturan Pemerintah No.17 Tahun 2010 bab IV Tentang Penyelenggaraan Pendidikan Jarak Jauh (PJJ)

Patilima, Hamdan. 2016 . Metode Penelitian Kualitatif. Bandung: Alfabeta.

Purwanto, Agus dkk. 2020. Studi Eksploratif Dampak Pandemi COVID-19 Terhadap Proses Pembelajaran Online di Sekolah Dasar. EduPsyCouns Journal. 2 (1) ISSN Online : 2716-4446.

Sam's, Rosma Hartiny. 2010. Model Penelitian Tindakan Kelas. Yogyakarta: Teras.

Sugiarto, Eko. 2015. Menyusun Proposal Penelitian Kualitatif Skripsi dan Tesis. Yogyakarta: Suaka Media. 
Sugiyono, 2012. Metode Penelitian Kuantitatif Kualitatif dan R\&D. Bandung: Alfabeta. 2012. Metode Penelitian Kuantitatif Kualitatif dan R\&D. Bandung: Alfabeta.

Susanto, A. 2013. Teori Belajar dan Pembelajaran di Sekolah. Jakarta: Kencana.

Undang-undang RI Nomor 20 Tahun 2003 Tentang Sistem Pendidikan Nasional.

Wikipedia. 2020.

Pendidikan Jarak

Jauh. https://id.m.wikipedia.org/wiki/Pendidikan jarak jauh (diakses pada tanggal 30 Mei 2020, pukul 11.37 WIB)

Yuliana. 2020. Coronavirus Disease (Covid-19). Wellness and Healthy Magazine. 2 (1): $187-$ 192.

Zhou, Wang, MD. 2020. Buku Panduan Pencegahan Coronavirus 101 Tips Berbasis Sains yang dapat Menyelamatka Hidup Anda. https://fin.co.id/wpcontent/uploads/2020/03/Buku-Panduan-Pencegahan-Coronavirus-101-TipsBerbasis-Sains.pdf (diakses pada tanggal 21 Mei 2020, pukul 22.18 WIB) 